\title{
Composition and selected properties of low pH mortars and concretes for radioactive waste repositories
}

\author{
An Cheng ${ }^{1, *}$, Wei-Ting Lin ${ }^{1}$, Sao-Jeng Chao ${ }^{1}$ and Hui-Mi $\mathrm{Hsu}^{1}$ \\ ${ }^{1}$ National Ilan University Department of Civil Engineering, No.1, Sec. 1, Shennong Rd., I-Lan 260, \\ Taiwan
}

\begin{abstract}
Conventional cementitious materials as tunnel supporting materials are utilised in the construction of the final repository for spent nuclear fuel. However, the use of cementitious material releases alkaline ions from $\mathrm{pH} 12$ to $\mathrm{pH} 13$ plumed into groundwater. Such a high $\mathrm{pH}$ is detrimental to the performance of the bentonite functioning, which may possibly enhance the dissolution and alteration of the fracture buffer and filling materials. Instead, low-pH cementitious materials are being developed for use in geological repositories. This study is aimed at evaluating the usability of low-pH cementitious materials containing $40 \%$ silica fume or composites blended with $20 \%$ silica fume and $40 \%$ fly ash. Engineering properties were analysed and verified through experimental research using the flow, compressive strength, $\mathrm{pH}$ measurement and hydraulic conductivity. Test results show that the replacement level with $40 \%$ of silica fume or $20 \%$ of silica fume and $40 \%$ of fly ash was suitable for the mixture of low-pH cementitious. Compared to the compressive strength and water permeability of ordinary cementitious, those of low-pH cementitious enhanced better engineered performances at the age of 91 days. The information is contributed us to establish the long-term durability and environmental requirements of disposal repositories in Taiwan.
\end{abstract}

\section{Introduction}

On the basis of preliminary feasibility assessment report for the spent nuclear fuel final disposal technology in 2009, canister design in Taiwan being studied with consideration to the preliminary design of a disposal concept using the Swedish canisters having the KBS3type copper canisters. The canisters are placed in the disposal tunnel and embedded in compacted bentonite. Swelled bentonite around with cementitious liner or plus as a canister system is designed to be used in high-level underground waste repositories. The low-pH cementitious in contact with bentonite is less than 11 in order to prevent the abnormally swelling of the bentonite and resultant detrimental effects to the host rock. Consequently,

\footnotetext{
*Corresponding author: ancheng@niu.edu.tw
} 
low-pH cementitious has been developed to be used in final disposal repositories for spent nuclear fuel [1].

The initial concept and mixture of low $\mathrm{pH}$ mortar or concrete as an engineering barrier was the result of experience gained by other waste management organisations, especially in Sweden [2-3], Japan [4] and Canada [5]. The use of traditional Portland cementitious materials gives a $\mathrm{pH}$ of between 12 to 13 and release alkalis and leachates which disrupts the functioning of bentonite. It was conducted to mix the low-pH cementitious materials (target is the $\mathrm{pH}$ below 11) in the leachates facilitate of the final disposal repositories.

To formulate a low $\mathrm{pH}$ cementitious material, the inclusion of Pozzolanic materials to partially replace the cement is feasible and advantageous [6]. Investigations of silica fume, fly ash and slag to partially replace cement have been carried out to produce low alkalinity, high workability and low heat cementitious materials [2-3, 7]. The $\mathrm{pH}$ formulation contributed by the usage amount of Portland cement. Low-pH cementitious materials had a lower amount of the $\mathrm{C} / \mathrm{S}$ ratio of $\mathrm{C}-\mathrm{S}-\mathrm{H}$, which enhances their sorption capacity of alkalis and reduces their equilibrium $\mathrm{pH}$ [8-10]. Owing to their fineness and chemical compositions, silica fume and metakaolin are much more reactive in the formulation of low $\mathrm{pH}$ cementitious materials and the suitable replacement of cement is in the range of $25 \%$ to $40 \%$ depending on the previous studies [11-12]. This study aims to identify appropriate mix designs for low-pH cementitious materials for suitable materials including silica fume, slag and fly ash. Measurements of $\mathrm{pH}$, compressive strength and water permeability are explicit explored and compared in this study.

\section{Materials and test procedures}

The mix designs used in this study are formulated using the methods outlined in ACI 211.1. One water-cement ratio (w/c) of 0.50 was used in the mixture as listed in Table 1 . Type I Portland cement with a specific gravity of 3.15 was used in accordance with ASTM C150. The specific gravity of natural fine aggregates and coarse aggregates in saturated surface dry condition was 2.70 and 2.36, respectively; the absorption of natural fine aggregates was 2.66. The absorption of fine aggregates and coarse aggregates was $1.63 \%$ and $1.37 \%$, respectively. The maximum size of coarse aggregate was $19 \mathrm{~mm}$ and the fineness modulus of the fine aggregate was 2.87 . The mixture proportions of the low-pH blended materials are summarised in Table 2 .

Silica fume with a specific gravity of 2.18 and a surface area of $22,500 \mathrm{~m}^{2} / \mathrm{kg}$ was used. The particle size of silica fume was around $0.1-0.2 \mu \mathrm{m}$ and the total content of $\mathrm{SiO}_{2}$ was more than $90 \%$. The specific gravity of class $\mathrm{F}$ fly ash was 2.17 and the total content of $\mathrm{SiO}_{2}+\mathrm{Al}_{2} \mathrm{O}_{3}+\mathrm{Fe}_{2} \mathrm{O}_{3}$ was more than $90.6 \%$. In addition, the slag has a specific surface area of $5,892 \mathrm{~m}^{2} / \mathrm{kg}$ and the specific gravity of the slag was 2.88 . Its major chemical constituents were $\mathrm{CaO}(40.24 \%), \mathrm{SiO}_{2}(33.68)$ and $\mathrm{Al}_{2} \mathrm{O}_{3}(14.37 \%)$.

The coding used to identify "Mix No." in column one of Table 1 should be read as 2 codes: The first character ("C" or " $\mathrm{M}$ ") indicates the specimen type (concrete or mortar, respectively). The second code (" 0 " to " 9 ") indicates the mixture proportions of low-pH blended materials as shown in Table 2 .

Table 1. Mix Design $\left(\mathrm{kg} / \mathrm{m}^{3}\right)$

\begin{tabular}{|c|c|c|c|c|c|c|c|c|c|}
\hline $\begin{array}{c}\text { Mix } \\
\text { no. }\end{array}$ & w/c & water & cement & $\begin{array}{l}\text { silica } \\
\text { fume }\end{array}$ & $\begin{array}{l}\text { fly } \\
\text { ash }\end{array}$ & slag & $\begin{array}{c}\text { fine } \\
\text { aggregates }\end{array}$ & $\begin{array}{c}\text { coarse } \\
\text { aggregates }\end{array}$ & SP \\
\hline $\mathrm{C} 0$ & \multirow{2}{*}{0.5} & 214 & 428 & 0 & 0 & 0 & \multirow{2}{*}{716} & \multirow{2}{*}{946} & 0 \\
\hline $\mathrm{C} 1$ & & 205 & 257 & 171 & 0 & 0 & & & 9 \\
\hline
\end{tabular}




\begin{tabular}{|c|c|c|c|c|c|c|c|c|c|}
\hline $\mathrm{C} 2$ & & 203 & 214 & 214 & 0 & 0 & & & 11 \\
\hline $\mathrm{C} 3$ & & 209 & 161 & 139 & 128 & 0 & & & 5 \\
\hline $\mathrm{C} 4$ & & 210 & 171 & 86 & 171 & 0 & & & 4 \\
\hline C5 & & 208 & 150 & 150 & 128 & 0 & & & 6 \\
\hline C6 & & 201 & 171 & 257 & 0 & 0 & & & 13 \\
\hline C7 & & 209 & 86 & 139 & 0 & 203 & & & 5 \\
\hline C8 & & 207 & 141 & 171 & 58 & 58 & & & 7 \\
\hline C9 & & 210 & 86 & 86 & 86 & 171 & & & 4 \\
\hline M0 & \multirow{10}{*}{0.6} & 320 & 493 & 0 & 0 & 0 & \multirow{10}{*}{1480} & \multirow{10}{*}{0} & 0 \\
\hline M1 & & 310 & 296 & 197 & 0 & 0 & & & 10 \\
\hline M2 & & 308 & 247 & 247 & 0 & 0 & & & 12 \\
\hline M3 & & 314 & 185 & 160 & 148 & 0 & & & 6 \\
\hline M4 & & 317 & 197 & 99 & 197 & 0 & & & 3 \\
\hline M5 & & 313 & 173 & 173 & 148 & 0 & & & 7 \\
\hline M6 & & 305 & 197 & 296 & 0 & 0 & & & 15 \\
\hline M7 & & 314 & 99 & 160 & 0 & 234 & & & 6 \\
\hline M8 & & 312 & 163 & 197 & 67 & 67 & & & 8 \\
\hline M9 & & 317 & 99 & 99 & 99 & 197 & & & 3 \\
\hline
\end{tabular}

Table 2. Composition of low $\mathrm{pH}$ blended binders

\begin{tabular}{|c|c|c|c|c|}
\hline Mix no. & cement $(\boldsymbol{\%})$ & silica fume (\%) & fly ash (\%) & slag (\%) \\
\hline C0/M0 & 100 & 0 & 0 & 0 \\
\hline C1/M1 & 60 & 40 & 0 & 0 \\
\hline C2/M2 & 50 & 50 & 0 & 0 \\
\hline C3/M3 & 37.5 & 32.5 & 30 & 0 \\
\hline C4/M4 & 40 & 20 & 30 & 0 \\
\hline C5/M5 & 35 & 35 & 0 & 0 \\
\hline C6/M6 & 40 & 60 & 0 & 47.5 \\
\hline C7/M7 & 20 & 32.5 & 40 & 0 \\
\hline
\end{tabular}




\begin{tabular}{|c|c|c|c|c|}
\hline C8/M8 & 33 & 40 & 13.5 & 13.5 \\
\hline C9/M9 & 20 & 20 & 20 & 40 \\
\hline
\end{tabular}

For each mix, twelve $\phi 100$ x $200 \mathrm{~mm}$ specimens per series were tested for compressive strength in accordance with ASTM C39 at the age of 7, 28, 56 and 91 days. Twelve $\phi 150 \mathrm{x}$ $150 \mathrm{~mm}$ specimens per series were tested for water permeability at the age of 28, 56 and 91 days in accordance with CRD C48. The powders ground from the specimens per series were tested for $\mathrm{pH}$ measurement at the age of 7, 28, 56 and 91 days following the specification of ASTM E70. The flow of mortar specimens and the slump of concrete specimens were tested following the specifications of ASTM C230 and ASTM C143, respectively. In this study, all measurements are presented as the average obtained from three specimens. The acceptance criteria of compressive strength, water permeability and $\mathrm{pH}$ measurement were $27.5 \mathrm{MPa}$, less than $10^{-8} \mathrm{~m} / \mathrm{s}$ and 11 , respectively.

Table 3. Test methods for specimens

\begin{tabular}{|c|c|c|c|}
\hline Test methods & $\begin{array}{c}\text { Specimen dimensions } \\
(\mathbf{m m})\end{array}$ & $\begin{array}{c}\text { Referred } \\
\text { standard }\end{array}$ & $\begin{array}{c}\text { Testing age } \\
(\mathbf{d a y s})\end{array}$ \\
\hline flow test & - & ASTM C1437 & - \\
\hline $\begin{array}{c}\text { compressive strength } \\
\text { test }\end{array}$ & $50 \times 50 \times 50$ & ASTM C109 & $7,28,56,91$ \\
\hline $\mathrm{pH}$ measure & powders & ASTM D1067 & $7,28,56,91$ \\
\hline water permeability & $\phi 150 \times 150$ & CRD C48 & $28,56,91$ \\
\hline
\end{tabular}

\section{Results and discussion}

Results of the flow test of mortar specimens and the slump test of concrete specimens for all mixtures are illustrated in Figs. 1 and 2, respectively. It can be found that the flow ability of the low-pH mortar had a similar trend of good workability due to the inclusion of the superplasticizer. The slump of the low-pH concrete was controlled as $21 \mathrm{~cm}$ except for the $\mathrm{C} 3$ specimens. The slump of the low-pH concrete after mixing increased strongly with their silica fume content, which was counteracted by adding increasing amounts of superplasticizer.

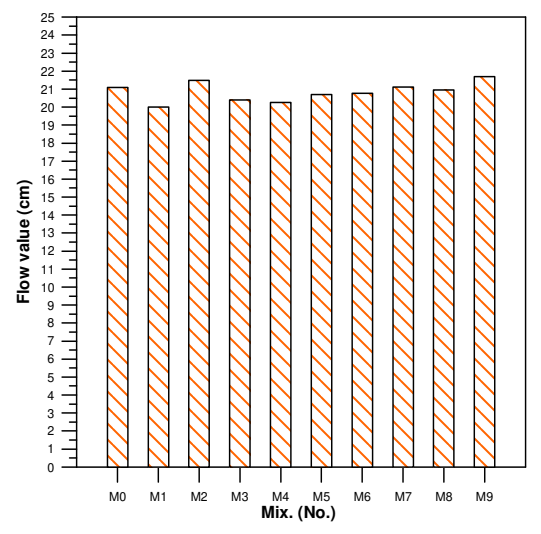

Fig. 1. Flow-test bar charts

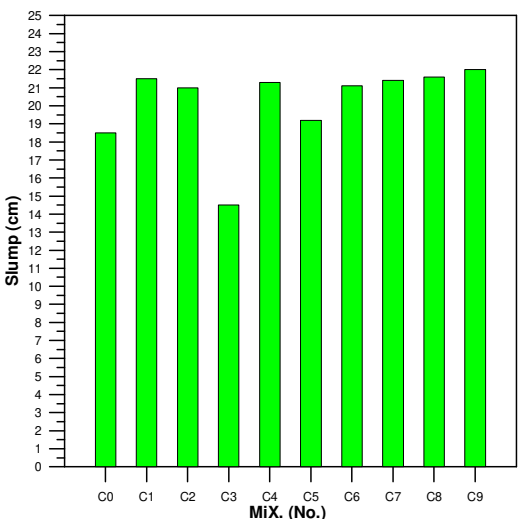

Fig. 2. Slump-test bar charts 
Compressive strength development curves of low-pH concrete and mortar specimens are illustrated in Figs. 3 and 4, respectively. The compressive strength increased with increases to the curing age and the amount of pozzolanic additives. The strength of all specimens at the age of 28 days reached $27.5 \mathrm{MPa}$, which is the requirement for the compressive strength of low-pH cementitious materials. However, the compressive strength of the concrete and mortar specimens containing fly ash had lower strength (similar to the control specimens), the result in this study still satisfies the design criteria ( $\geq 27.5 \mathrm{MPa}$ at 28 days). In addition, the inclusion of silica fume in cementitious materials was used to increase the ultimate strength and gave the highest strength due to both the microfiller effects and the pozzolanic effects, which is consistent with the pervious literature [13]. The low-pH cementitious material formulation $(60 \%$ cement $+40 \%$ silica fume formulation) was evaluated in the case of concrete and mortar as it was suitable for the construction of low-pH cementitious materials due to its higher strength.

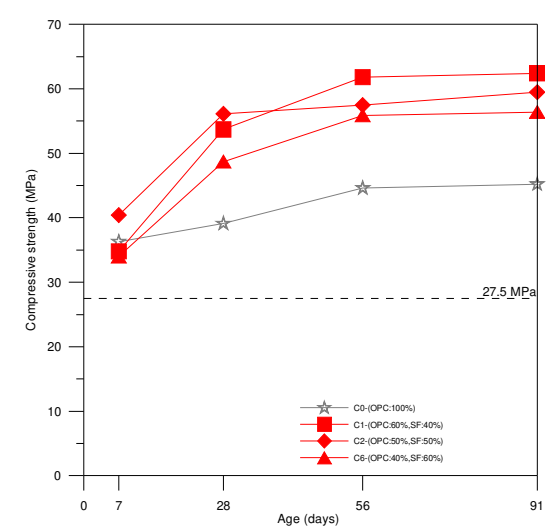

(a) low-pH concrete containing silica fume

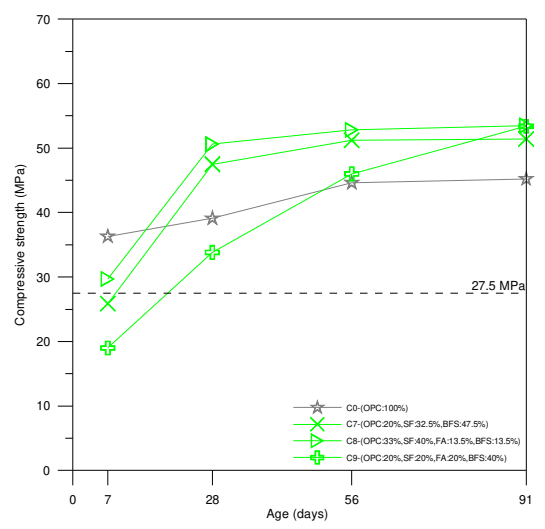

(c) low-pH concrete containing slag

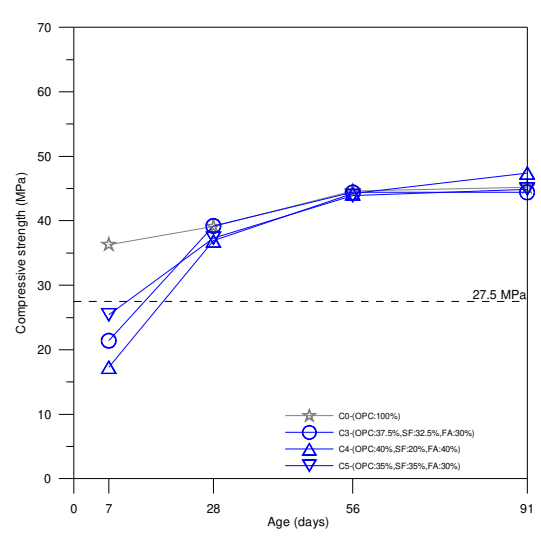

(b) low-pH concrete containing fly ash

Fig. 3. Compressive strength development curves of concrete 


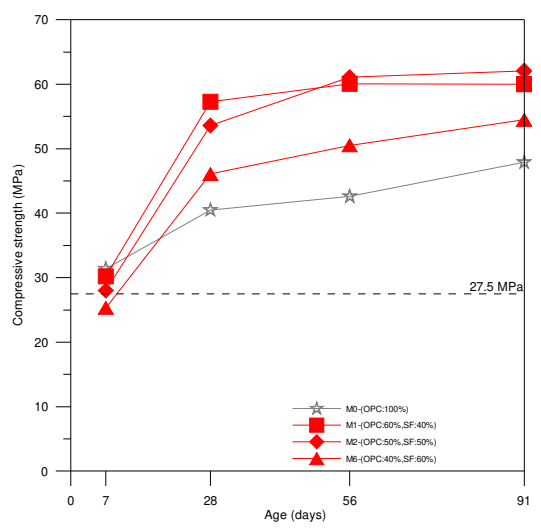

(a) low-pH mortar containing silica fume

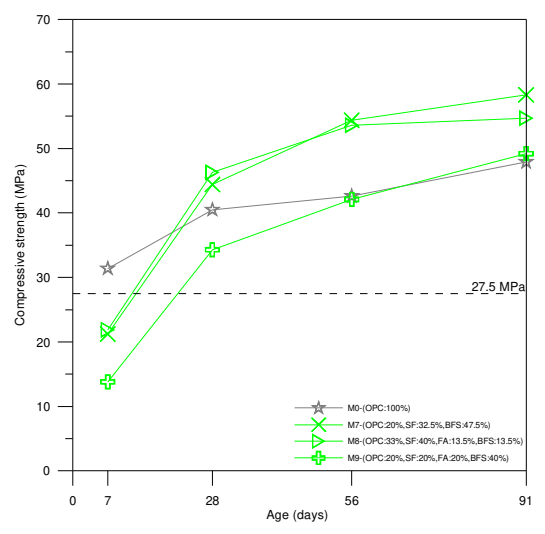

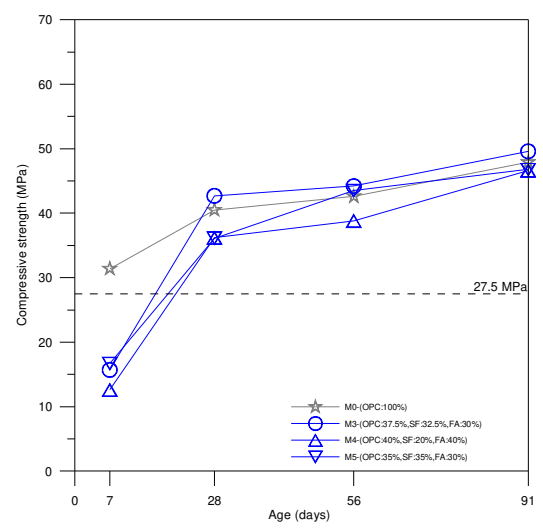

(b) low-pH mortar containing fly ash

(c) low-pH mortar containing slag

Fig. 4. Compressive strength development curves of mortar

In the case of their pore fluid $\mathrm{pH}$, the $\mathrm{pH}$ value of various specimens can be seen in Figs. 5 and 6. The $\mathrm{pH}$ decreased as the curing age increased and lowered to below $\mathrm{pH} 11$ after the age of 28 days, except for the C7, C9, M7 and M9 specimens. The use of low-pH cementitious materials with lower $\mathrm{pH} \leq 11$ could thus decrease the diffusive transport of hydroxyl ions by two orders of magnitude in comparison with fluids leached from original cement materials [14]. The $\mathrm{pH}$ maintained a stable value of around 10.5 in the long term (from 56 days to 91 days). According to the findings of the previous study, the degradation of cementitious materials tended to lower the $\mathrm{Ca} / \mathrm{Si}$ ratio because of the incongruent dissolution preferential release of $\mathrm{Ca}$ over $\mathrm{Si}$ [15]. The $\mathrm{pH}$ decreased smoothly with decreasing $\mathrm{Ca} / \mathrm{Si}$ for cementitious materials. It also indicated that the higher silica fume content tended to decrease the $\mathrm{pH}$ more over time than those with lower silica fume content or fly ash and slag content. All mixtures of concrete and mortar specimens exceed the target compressive strength of $27.5 \mathrm{MPa}$; however, only seven mixture proportions of low-pH blended materials kept the target $\mathrm{pH}$ value of 11 . 


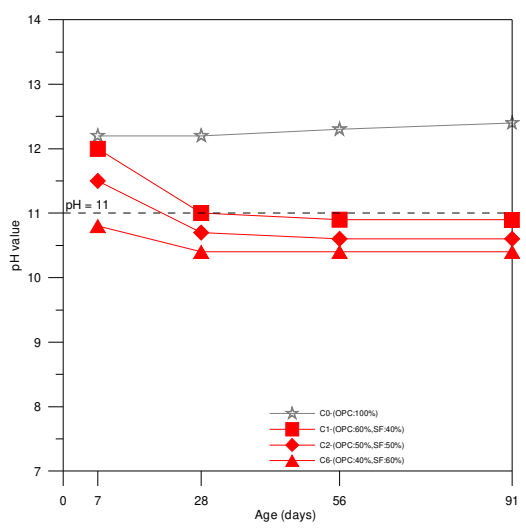

(a) low-pH concrete containing silica fume

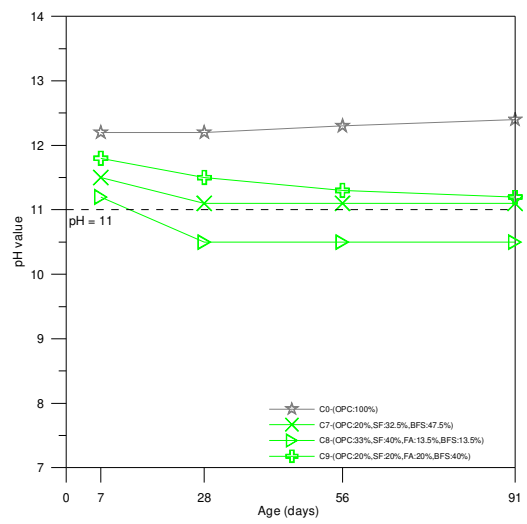

(c) low-pH concrete containing slag

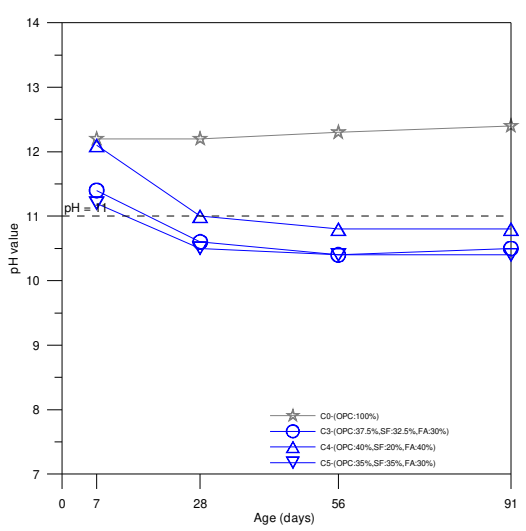

(b) low-pH concrete containing fly ash

Fig. 5. $\mathrm{pH}$ variability of concrete during maturing

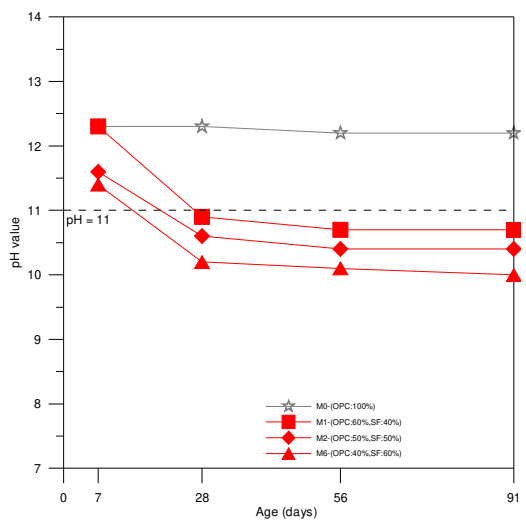

(a) low-pH mortar containing silica fume

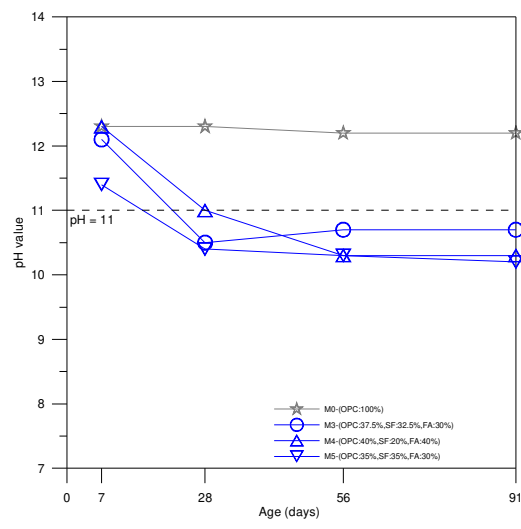

(b) low-pH mortar containing fly ash 


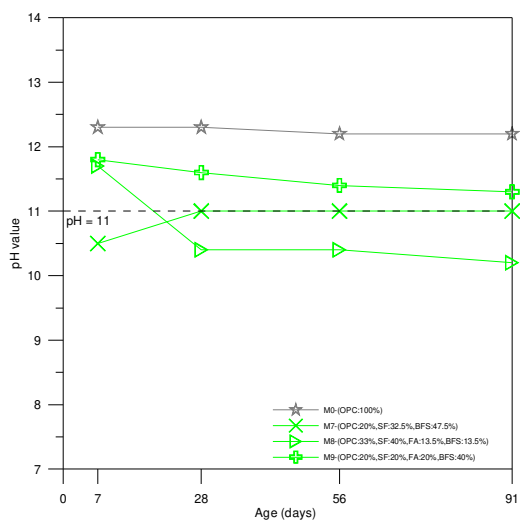

(c) low-pH mortar containing slag

Fig. 6. $\mathrm{pH}$ variability of mortar during maturing

The results of the water permeability coefficients for low-pH concrete and mortar specimens measured at ages of 28, 56 and 91 days are illustrated in Figs. 7 and 8, respectively. It can be seen that the water permeability coefficient can be calculated using the Darcy formula as follows:

$$
k=\frac{Q L \rho}{A P}
$$

where $\mathrm{L}$ is the length of flow path $(\mathrm{cm})$; $\mathrm{Q}$ is the flow rate $\left(\mathrm{cm}^{3} / \mathrm{s}\right)$; $\mathrm{A}$ is the area of the permeable medium perpendicular to flow $\left(\mathrm{cm}^{2}\right) ; \mathrm{P}$ is the water pressure $\left(\mathrm{kg} / \mathrm{cm}^{2}\right) ; \rho$ is the water density $\left(\mathrm{kg} / \mathrm{m}^{3}\right) ; k$ is the permeability coefficient $(\mathrm{m} / \mathrm{s})$. The target water permeability coefficient of low-pH cementitious materials is less than $10^{-8} \mathrm{~m} / \mathrm{s}$ and the permeability coefficient of all mixtures meets the acceptance criteria. The permeability coefficient of these low-pH cementitious materials is lower than that of the surrounding rock (around $1 \sim 0.1 \times 10^{-9} \mathrm{~m} / \mathrm{s}$ ). However, the inclusion of silica fume and slag mixed with low-pH cementitious materials simultaneously acted to reduce the permeability and enhance the long-term durability.

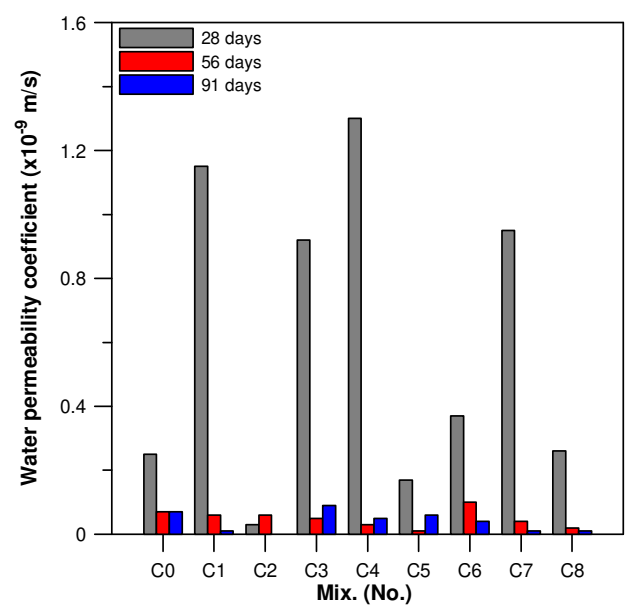

Fig. 7. Water permeability coefficients bar charts of concrete specimens 


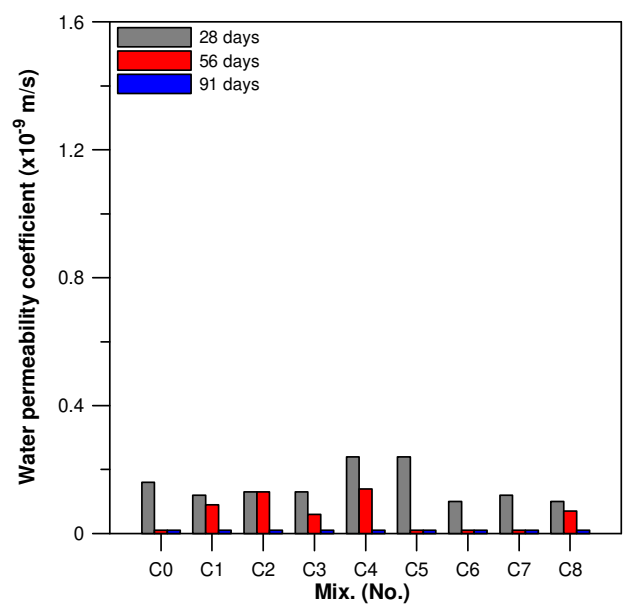

Fig. 8. Water permeability coefficients bar charts of moratr specimens

\section{Conclusions}

- On the basis of the acceptance criteria of compressive strength, water permeability and $\mathrm{pH}$ measurement, the replacement level with $40 \%$ of silica fume (C1 and M1) or $20 \%$ of silica fume and $40 \%$ of fly ash (C4 and M4) is suitable for the mixture of low-pH cementitious material.

- The $\mathrm{pH}$ measurement of $\mathrm{C} 1, \mathrm{C} 4, \mathrm{M} 1$ and M4 specimens gets close to a constant of 10.5 after around 56 days and the $\mathrm{pH}$ requirement $(\mathrm{pH}<11)$ is obtained after 28 days.

- Compared to the control specimens (Co and M0), the C1, and M1 specimens have higher compressive strength due to the larger content of silica fume. This may reflect the denser micro-structures and better mechanical properties.

- For the properties of low-pH cementitious materials, there is little information on the long-term cementitious degradation with regard to durability and ensuring a watertight repository structure, especially for periods of over 100 years. Furthermore, it is important to study material degradation including leaching and the chemical stability of the low-pH cementitious materials in final disposal repositories.

Acknowledgements: This work has been financed by the Polish National Agency for Academic Exchange under the International Academic Partnership Programme within the framework of the grant: E-mobility and sustainable materials and technologies EMMAT.

\section{References}

1. C. C. D. Coumes, S. Courtois, D. Nectoux, S. Leclercq, X. Bourbone, Cement Concrete Res. 36, 2152 (2006).

2. C. Vogt, B. Lagerblad, K. Wallin, F. Baldy, Low pH self-compacting concrete for deposition tunnel plugs (Stockholm 2012)

3. R. Malm, Low-pH concrete plug for sealing the KBS-3V deposition tunnels (Svensk Kärnbränslehantering (Stockholm 2012)

4. K. Yamaji, Issues of HLW Disposal in Japan, Chapter of Nuclear Back-end and Transmutation Technology for Waste Disposal, 279-287 (Springer Tokyo Heidelberg New York Dordrecht London (2015) 
5. J. Martino, D. Dixon, B. Holowick, C. S. Kim, Seal Construction and Instrumentation Report (Atomic Energy of Canada Limited) (2011).

6. T. L. P. Hang, J. Verdier, T. Vidal, G. Camps, X. Bourbon, Eur. J. Environ. Civ. Eng. 23, 657 (2017).

7. C. C. D. Coumes, S. Courtois, S. Leclercq, X. Bourbone, An International Conference on Advances For Future. Nuclear Fuel Cycles 21-25 (Atalante 2004)

8. P. L. Rayment, Cement Concrete Res. 12, 133 (1982).

9. S. Y. Hong, F.P. Glasser, Cement Concrete Res. 29, 1893 (1999).

10. J. L. García Calvo, M. S. Moreno, M. C. A. Alonso, A. H. López, J. G. Olmo, Materials 6, 2508 (2013).

11. M. C. Alonso, L. F. Luco, J. L. Garcia, A. Hidalgo, F. Huertas, Proceedings of the 12th International Congress on the Chemistry of Cement, Montreal, 15, (2007).

12. P. Krivenko, O. Petropavlovskyi, E. Kavalerova, RILEM, Dordrecht, 395-401, (2015).

13. S. Bhanja, B. Sengupta, ACI Mate. J. 100, 407 (2003).

14. S. David, S. J. Benbow, SKI Report 2007, 32, 2007.

15. J. M. Soler, Posiva Working Report 2007-88, (Posiva Oy 2007) 